\title{
Pharmacological Characterization of the Receptor Mediating the Anorexigenic Action of the Octadecaneuropeptide: Evidence for an Endozepinergic Tone Regulating Food Intake
}

\author{
Jean-Claude do Rego*,', Marie-Hélène Orta', Jérôme Leprince², Marie-Christine Tonon², Hubert Vaudry ${ }^{2}$ \\ and Jean Costentin' \\ 'CNRS FRE 2735, Laboratory of Experimental Neuropsychopharmacology, European Institute for Peptide Research (IFRMP 23), Faculty of \\ Medicine and Pharmacy, University of Rouen, Rouen Cedex, France; ${ }^{2}$ Inserm U4 I3, Laboratory of Cellular and Molecular Neuroendocrinology, \\ European Institute for Peptide Research (IFRMP 23), University of Rouen, Mont-Saint-Aignan, France
}

Peptides of the endozepine family, including diazepam-binding inhibitor, the triakontatetraneuropeptide, and the octadecaneuropeptide $(\mathrm{ODN})$, act through three types of receptors, that is, central-type benzodiazepine receptors (CBR), peripheral-type (mitochondrial) benzodiazepine receptors (PBR) and a metabotropic receptor positively coupled to phospholipase $C$ via a pertussis toxin-sensitive $G$ protein. We have previously reported that ODN exerts a potent anorexigenic effect in rat and we have found that the action of ODN is not affected by the mixed CBR/PBR agonist diazepam. In the present report, we have tested the possible involvement of the metabotropic receptor in the anorexigenic activity of ODN. Intracerebroventricular administration of the C-terminal octapeptide (OP) and its head-to-tail cyclic analog cyclo,-8 $\mathrm{OP}(\mathrm{COP})$ at a dose of $100 \mathrm{ng}$ mimicked the inhibitory effect of ODN on food intake in fooddeprived mice. The specific CBR antagonist flumazenil and the PBR antagonist PKI I 195 did not prevent the effect of ODN, OP, and cOP on food consumption. In contrast, the selective metabotropic endozepine receptor antagonist cyclo I-8 $\left[\mathrm{DLeu}{ }^{5}\right] \mathrm{OP}(\mathrm{IO0}-1000 \mathrm{ng} ; \mathrm{CDLOP})$ suppressed the anorexigenic effect of ODN, OP, and cOP. At the highest concentration tested ( 1000 ng), cDLOP provoked by itself a significant increase in food intake. Taken together, the present results indicate that the anorexigenic effect of ODN and OP is mediated through activation of the metabotropic receptor recently characterized in astrocytes. The data also suggest that endogenous ODN, acting via this receptor, exerts an inhibitory tone on feeding behavior.

Neuropsychopharmacology (2007) 32, I64I-1648; doi:I0. I038/sj.npp. I 301280; published online 6 December 2006

Keywords: endozepines; diazepam-binding inhibitor; octadecaneuropeptide; feeding behavior; metabotropic receptors; mouse

\section{INTRODUCTION}

The term endozepines designates a family of regulatory neuropeptides that have been originally isolated from rat brain extracts on the basis of their ability to displace benzodiazepines from their binding sites (Guidotti et al, 1983; Tonon et al, 2006). All endozepines characterized so far derive from diazepam-binding inhibitor (DBI), an 86 amino-acid polypeptide precursor which has the potential to generate several biologically active fragments including the triakontatetraneuropeptide $\mathrm{DBI}_{17-50}$ (TTN) (Slobodyansky et al, 1989) and the octadecaneuropeptide $\mathrm{DBI}_{33-50}$

\footnotetext{
*Correspondence: Dr J-C do Rego, CNRS FRE 2735, Laboratory of Experimental Neuropsychopharmacology, European Institute for Peptide Research (IFRMP 23), Faculty of Medicine and Pharmacy, University of Rouen, 22 Boulevard Gambetta, 76I83 Rouen Cedex, France, Tel: + 332 35|48602, Fax: + 33235 |48603,

E-mail: jean-claude.dorego@univ-rouen.fr

Received I August 2006; revised 16 October 2006; accepted 17 October 2006
}

(ODN) (Ferrero et al, 1986). The DBI gene is widely expressed in the central nervous system (Alho et al, 1988; Tong et al, 1991; Yanase et al, 2002). In particular, high concentrations of endozepines have been found in brain areas which play a major role in the control of feeding behavior such as the arcute nucleus, the dorso-medial and ventro-medial hypothalamic nuclei, and the lateral hypothalamic area (Alho et al, 1985; Malagon et al, 1993; Tonon et al, 1990).

Intracerebroventricular (i.c.v.) injection of low doses of ODN causes a marked reduction of food consumption in both food deprived and normally fed rodents (Garcia de Mateos-Verchere et al, 2001). The anorexigenic effect of ODN is long lasting, does not give rise to rapid tolerance, and is associated with a substantial loss of weight (Garcia de Mateos-Verchere et al, 2001). In rats deprived of food for $12 \mathrm{~h}$, i.c.v. administration of ODN reduces the expression of neuropeptide Y (NPY), an orexigenic neuropeptide, and activates the expression of proopiomelanocortin, the precursor of the anorexigenic peptide $\alpha$-melanocyte-stimulating hormone (Compère et al, 2003, 2005), suggesting that 
NPY- and POMC-producing neurons of the arcute nucleus are involved in the anorexigenic effect of ODN.

The biological effects of endozepines are mediated through three types of receptors. DBI and ODN act as inverse agonists of central-type benzodiazepine receptors (CBR) associated with the $\mathrm{GABA}_{\mathrm{A}}$ receptor complex (Guidotti et al, 1983; Tonon et al, 1989; Bormann, 1991; Louiset et al, 1993). TTN acts preferentially through peripheral-type benzodiazepine receptors (PBR) located either at the outer mitochondrial membrane or at the plasma membrane level (Guidotti et al, 1989; Berkovich et al, 1990; Gandolfo et al, 2001). Finally, ODN can also activate a metabotropic receptor positively coupled to phospholipase C through a pertussis toxin-sensitive G-protein (Patte et al, 1995; Gandolfo et al, 1997). We have previously shown that the anorexigenic effect of ODN was not affected by the mixed CBR/PBR agonist diazepam (Garcia de MateosVerchere $e t a l, 2001$ ). The aim of the present study was to investigate the possible involvement of the metabotropic receptor in the action of endozepines on feeding behavior.

\section{MATERIALS AND METHODS}

\section{Animals}

Male Swiss albinos CD1 mice (Iffa-Credo/Charles River, Saint-Germain sur l'Arbresle, France), weighing 22-25g, were housed 20 in Makrolon cages (L: $40 \mathrm{~cm}, \mathrm{~W}: 25 \mathrm{~cm}$, and $\mathrm{H}: 18 \mathrm{~cm}$ ), with free access to standard semisynthetic laboratory diet (U.A.R., Villemoisson-sur-Orge, France) and tap water. The animals were kept in a ventilated room at a temperature of $22 \pm 1^{\circ} \mathrm{C}$ under a 12-h light/12-h dark cycle (light on between 0700 and 1900).

All the experiments were carried out between 0900 and 1800 in testing rooms adjacent to the animal rooms. Animal manipulations were performed according to the European Community Council Directive of 24 November 1986 (86:609:EEC), were approved by the local Ethical Committee (authorization numbers: N/10-04-04-12 and N/13-04-04-15) and were conducted by authorized investigators. Each animal was used once and then immediately killed.

\section{Drugs and Solutions}

The metabotropic endozepine receptor agonists ODN (Gln-Ala-Thr-Val-Gly-Asp-Val-Asn-Thr-Asp-Arg-Pro-GlyLeu-Leu-Asp-Leu-Lys), octapeptide (OP) (Arg-Pro-GlyLeu-Leu-Asp-Leu-Lys) and cyclo $_{1-8} \mathrm{OP}$ (Arg-Pro-Gly-LeuLeu-Asp-Leu-Lys; cOP), and the metabotropic endozepine receptor antagonist cyclo $_{1-8}\left[\mathrm{DLeu}^{5}\right] \mathrm{OP}$ (Arg-Pro-Gly-LeuDLeu-Asp-Leu-Lys; cDLOP) were synthesized by solid phase methodology as described previously (Leprince et al, 1998, 2001). The peptides were dissolved in saline $(0.9 \% \mathrm{NaCl})$. Flumazenil (Ro 15-1788) and PK11195 (Sigma Aldrich, Saint-Quentin Fallavier, France) were dissolved in 2.5\% dimethylsulfoxide in saline. For PK11195, 0.5\% Tween-80 was added to facilitate solubilization. All solutions were prepared just before injections.

\section{I.c.v. Injection}

Free-hand i.c.v. injections ( $10 \mu \mathrm{l} /$ mouse) of saline, peptides and/or drugs were made in the left ventricle according to the procedure of Haley and McCormick (1957), using a microsyringe ( $50 \mu \mathrm{l}$; Hamilton, Bonaduz, Switzerland) connected to a needle (diameter $0.5 \mathrm{~mm}$ ), of which the bevel protruded only $3.5 \mathrm{~mm}$ from a guard limiting its penetration into the brain. The injection in immobilized mice lasted approximately $5 \mathrm{~s}$. I.c.v. injections were performed by an experienced investigator, who frequently controlled the regularity and success of the injections, using methylene blue dye and who observed (after killing and frontal brain sectioning) that the injection was successful in more than $95 \%$ of the trials. The i.c.v. injection method was approved by the Regional Ethical Committee for Animal Experimentation (Normandy; no. N/10-04-04-12).

\section{Food Consumption Experiments in Food-Deprived Mice or Food-Restricted Mice}

Two days before the experiments, mice were isolated in individual cages (L: $24 \mathrm{~cm}, \mathrm{~W}: 10$, and $\mathrm{H}: 7 \mathrm{~cm}$ ) with free access to water and the pellets of food laid down the floor of the cages, in order to make the animals accustomed to the test conditions. For experiments with food-deprived mice (fasted mice) (in order to evaluate an anorexigenic effect), $18 \mathrm{~h}$ before testing $(1500-0900 \mathrm{~h})$, animals were totally deprived of food and had access to tap water ad libitum. For experiments with food-restricted mice (in order to evaluate an orexigenic effect), $18 \mathrm{~h}$ before testing (1500$0900 \mathrm{~h}$ ), animals had access to only $3 \mathrm{~g}$ of food (that represented approximately half of their daily consumption) and water ad libitum. In all groups, mice had access to a weighed food pellet $(5 \mathrm{~g})$ deposited on the floor of the cage 10 min after i.c.v. administration of saline, peptides, and/or drugs. Thereafter, the pellet was briefly $(<20 \mathrm{~s})$ removed with forceps and weighed every $30 \mathrm{~min}$, for $3 \mathrm{~h}$. The food consumption method was approved by the Regional Ethical Committee for Animal Experimentation (Normandy; no. N/13-04-04-15).

\section{Measurement of Locomotor Activity}

Ten min after i.c.v. administration of saline or peptides, the animals were placed individually in $20 \times 20 \times 30 \mathrm{~cm}$ compartments, in a lighted and quiet room. Locomotor activity was assessed automatically in a Digiscan actimeter (Omnitech Electronics Inc, Colombus, $\mathrm{OH}$ ), which monitored the horizontal displacements and vertical movements, including rearing, leaning, and jumping. The responses were expressed as the total number of beams crossed by mice during four consecutive 15 -min periods.

\section{Statistical Analysis}

Data are expressed as means \pm SEM. Differences between groups were assessed by one-way analysis of variance (ANOVA) followed by a post hoc multiple comparison Student-Newman-Keuls test. Antagonistic effects were analyzed using two-way ANOVA, and a post hoc multiple comparison Student-Newman-Keuls test was used for multiple comparisons between groups. A probability level of 0.05 or lower was considered as statistically significant. 


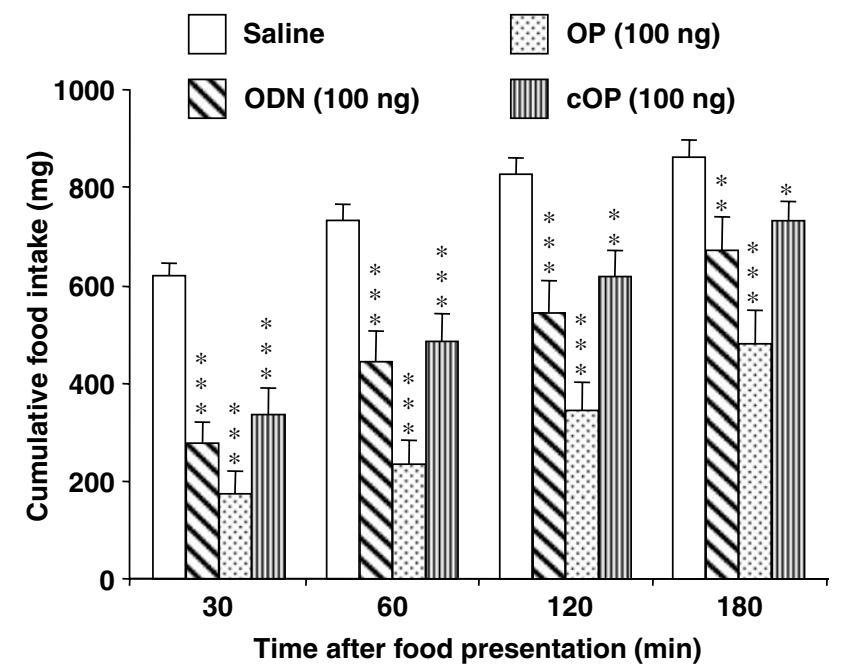

Figure I Time course of the effect of ODN, OP, or cOP on food intake in food-deprived mice. Mice deprived of food for $18 \mathrm{~h}$ were injected i.c.v. $(|0 \mu|)$ with saline, ODN (I00 ng/mouse), OP (I00 ng/mouse), or cOP(I $00 \mathrm{ng} /$ mouse). Ten min after i.c.v. injection, each animal had access to a weighed food pellet. Cumulative food intake was measured during $3 \mathrm{~h}$ at the time indicated. Mean \pm SEM represents data from 14 mice per group. Student-Newman-Keuls post hoc test: $* p<0.05$, *** $p<0.0$ I, ***** $p<0.00$ I vs saline-injected mice.
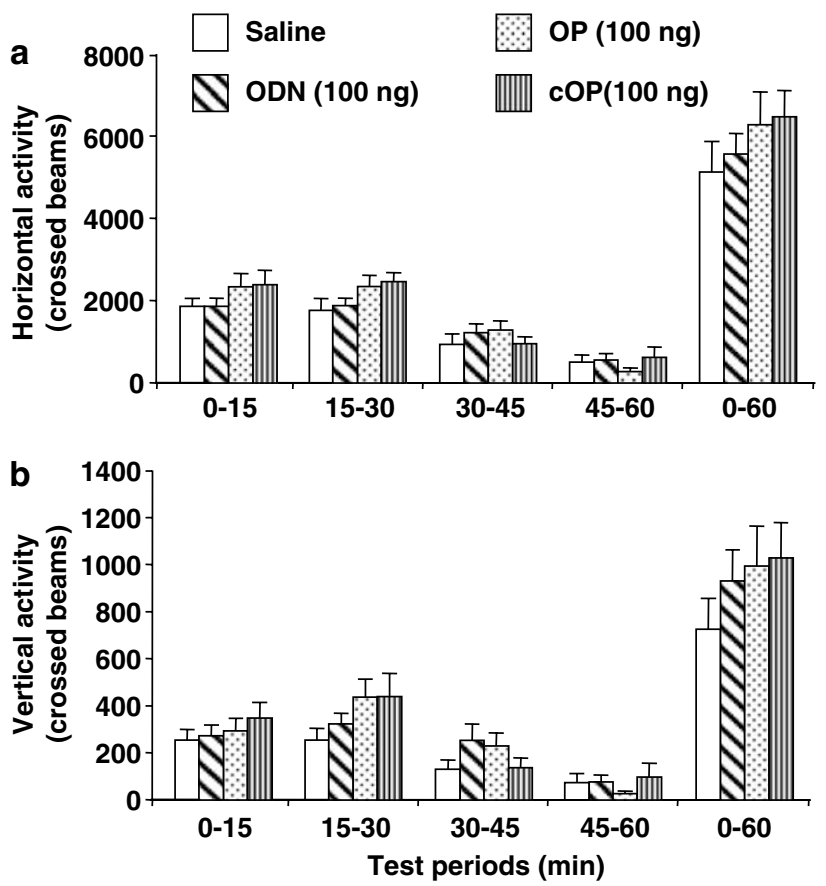

Figure 2 Effect of ODN, OP, or cOP on locomotor activity. Mice deprived of food for $18 \mathrm{~h}$ were injected i.c.v. $(10 \mu \mathrm{l})$ with saline, ODN (I00 ng/mouse), OP (I00 ng/mouse), or cOP (I00 ng/mouse). Ten min after i.c.v. injection, animals were introduced into the actimeters. The horizontal (a) and vertical (b) components of motor activity were measured during four consecutive periods of 10 min. Mean \pm SEM represents data from 12 mice per group.

\section{RESULTS}

Effects of ODN, OP, and cOP on Food Intake in Food-Deprived Mice

In food-deprived mice, i.c.v. injection of $100 \mathrm{ng}$ ODN, OP, or cOP significantly reduced $(p<0.001)$ food intake during

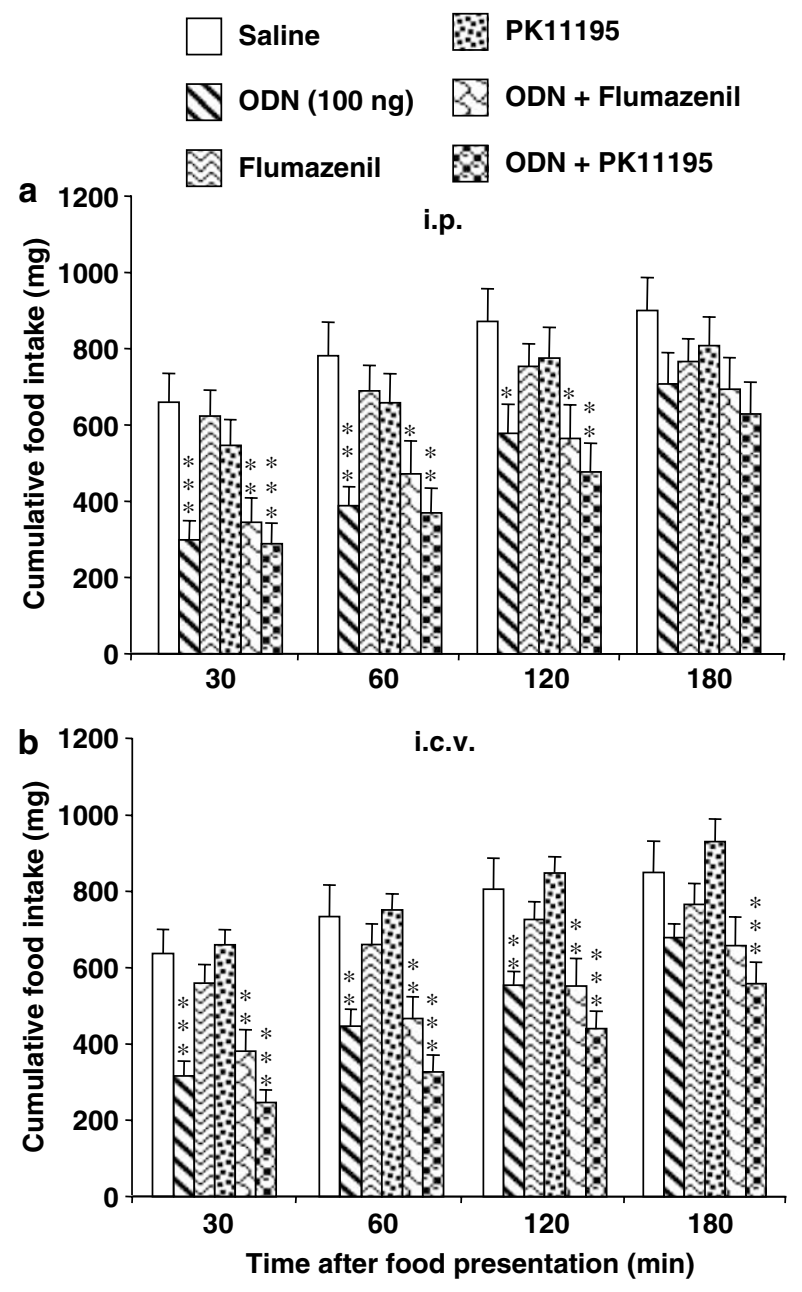

Figure 3 Effect of flumazenil and PKIII95 on ODN-induced inhibition of food intake in food-deprived mice. (a) Mice deprived of food for $18 \mathrm{~h}$ were injected i.p. with saline, flumazenil $(2 \mathrm{mg} / \mathrm{kg})$, or PKI I I 95 (2 mg/kg), 30 min before i.c.v. injection $(|0 \mu|)$ of saline, or ODN (I00 ng/mouse). (b) Mice deprived of food for $18 \mathrm{~h}$ were injected i.c.v. $(10 \mu \mathrm{l})$ with saline, ODN ( $100 \mathrm{ng} /$ mouse), flumazenil ( $2 \mu \mathrm{g} /$ mouse), PKI I I 95 ( $2 \mu \mathrm{g} / \mathrm{mouse})$, or with ODN plus flumazenil or PKII 195. Ten min after i.c.v. injection, each animal had access to a weighed food pellet. Cumulative food intake was determined during $3 \mathrm{~h}$ at the time indicated. Mean \pm SEM represents data from 14 mice per group. Student-Newman-Keuls post hoc test: $* p<0.05$, *** $p<0.01$, **** $p<0.001$ vs saline-injected mice.

the first 30 -min period of testing. The mean \pm SEM percentage of food intake inhibition induced by these peptides is: $55.3 \pm 6.8 \%$ for ODN, $68.9 \pm 8.1 \%$ for OP, and $51.5 \pm 7.4 \%$ for cOP. Thereafter, the anorexigenic effect of all three peptides gradually vanished but the cumulative food consumption remained significantly reduced during the whole 3-h test period (Figure 1).

\section{Effects of ODN, OP, and cOP on Locomotor Activity}

The influence of i.c.v. administration of ODN, OP, or COP on locomotor activity was measured over four consecutive periods of $15 \mathrm{~min}$ each (Figure 2). The peptides did not significantly modify horizontal (Figure 2a) and vertical (Figure 2b) locomotor activities at any time of the test period. 

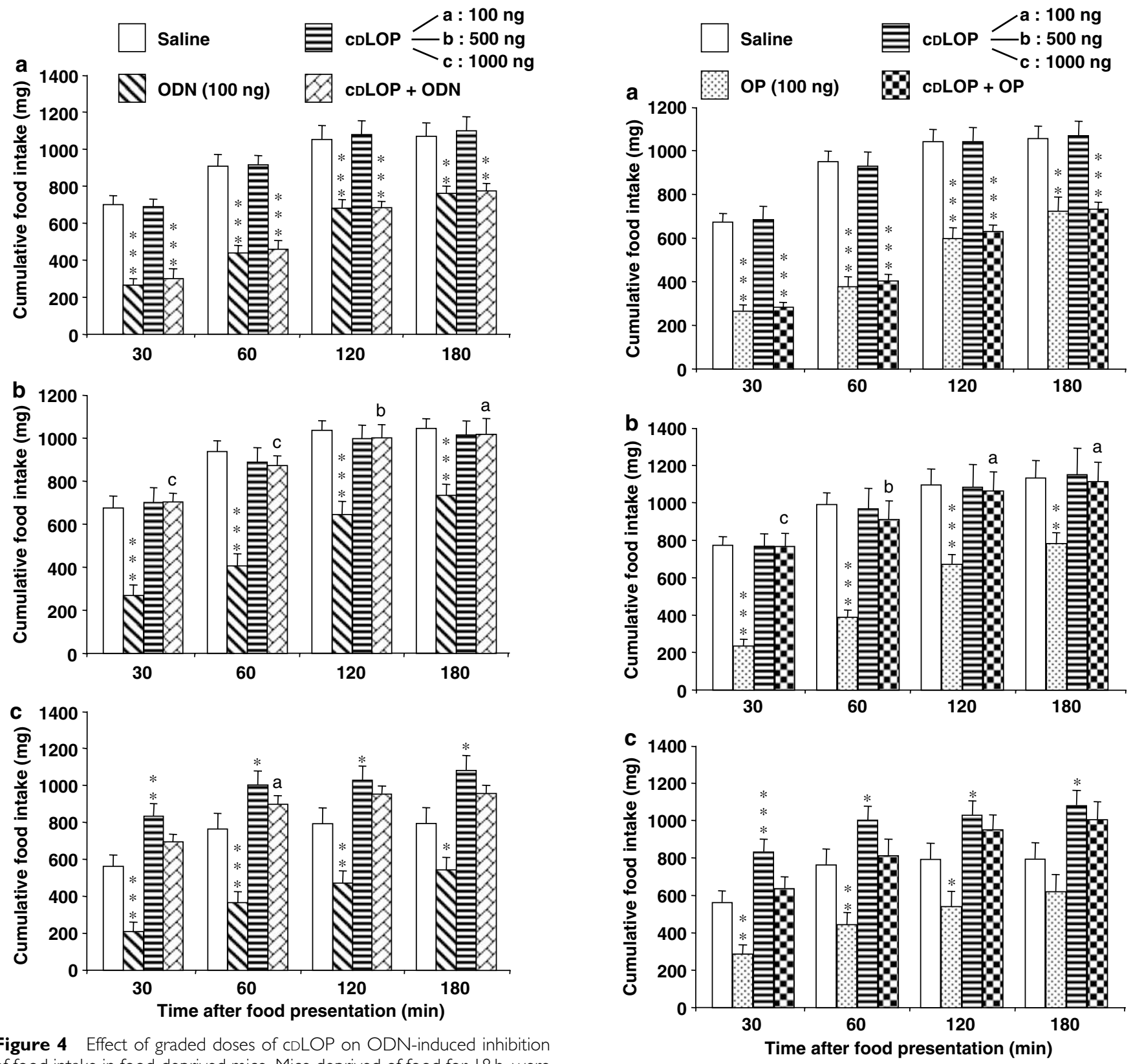

Figure 4 Effect of graded doses of CDLOP on ODN-induced inhibition of food intake in food-deprived mice. Mice deprived of food for $18 \mathrm{~h}$, were injected i.c.v. $(|0 \mu|)$ with saline, or ODN (I00 ng/mouse) in the absence or presence of increasing doses of cyclo ${ }_{-8}\left[\mathrm{DLeu}^{5}\right] \mathrm{OP}$ (CDLOP; a, I00 ng/ mouse; b, $500 \mathrm{ng} /$ mouse; c, $1000 \mathrm{ng} /$ mouse). Ten min after i.c.v. injection, each animal had access to a weighed food pellet. Cumulative food intake was measured during $3 \mathrm{~h}$ at the time indicated. Mean \pm SEM represents data from 10 to 24 mice per group. Student-Newman-Keuls test: $* p<0.05$, *** $p<0.01$, **** $<0.00$ I vs saline-injected mice. A two-way ANOVA revealed a significant interaction: between CDLOP (500 ng/ mouse) and ODN at $30 \mathrm{~min} F(1,36)=14.6, \quad c p<0.001$, at $60 \mathrm{~min}$ $F(1,36)=22.3, c_{p}<0.001$, at $120 \mathrm{~min} F(1,36)=11.9,{ }^{b} p<0.01$, and at $180 \mathrm{~min} F(\mid, 36)=7.2,{ }^{\mathrm{a}} \mathrm{p}<0.05$; and between cDLOP ( $\left.1000 \mathrm{ng} / \mathrm{mouse}\right)$ and ODN at 60 min after food presentation $F(I .52)=4.8,{ }^{a} p<0.05$.

Characterization of the Receptor Involved in the Anorexigenic Effects of ODN, OP, and cOP

To characterize the pharmacological profile of the receptor involved in the anorexigenic effect of ODN, food-deprived mice were treated with the CBR antagonist flumazenil, the

Figure 5 Effect of graded doses of CDLOP on OP-induced inhibition of food intake in food-deprived mice. Mice deprived of food for $18 \mathrm{~h}$, were injected i.c.v. $(|0 \mu|)$ with saline, or OP $(100 \mathrm{ng} /$ mouse $)$ in the absence or presence of increasing doses of cyclo - $_{-8}\left[\mathrm{DLeu}^{5}\right] \mathrm{OP}$ (CDLOP; a, I00 ng/ mouse; b, $500 \mathrm{ng} / \mathrm{mouse}$;, $1000 \mathrm{ng} / \mathrm{mouse})$. Ten min after i.c.v. injection, each animal had access to a weighed food pellet. Cumulative food intake was measured during $3 \mathrm{~h}$ at the time indicated. Mean \pm SEM represents data from 10 to 24 mice per group. Student-Newman-Keuls test: $* p<0.05$, *** $p<0.01$, **** $p<0.00$ I vs saline injected-mice. A two-way ANOVA revealed a significant interaction between CDLOP ( $500 \mathrm{ng} / \mathrm{mouse})$ and $\mathrm{OP}$ at $30 \mathrm{~min} F(I, 44)=23.3,{ }^{c} p<0.00 \mathrm{I}$, at $60 \mathrm{~min} F(I, 44)=10.9$, ${ }^{b} p<0.01$, at $120 \min F(I, 44)=4.4,{ }^{a} p<0.05$, and at $180 \min F(I, 44)=4.2$, $a p<0.05$.

PBR antagonist PK11195, or the metabotropic receptor antagonist cDLOP. Intraperitoneal (i.p.) and i.c.v. administration of flumazenil or PK11195 alone did not modify spontaneous food consumption (Figure $3 \mathrm{a}$ and $\mathrm{b}$ ). Similarly, i.p. injection of flumazenil or PK11195, $30 \mathrm{~min}$ 

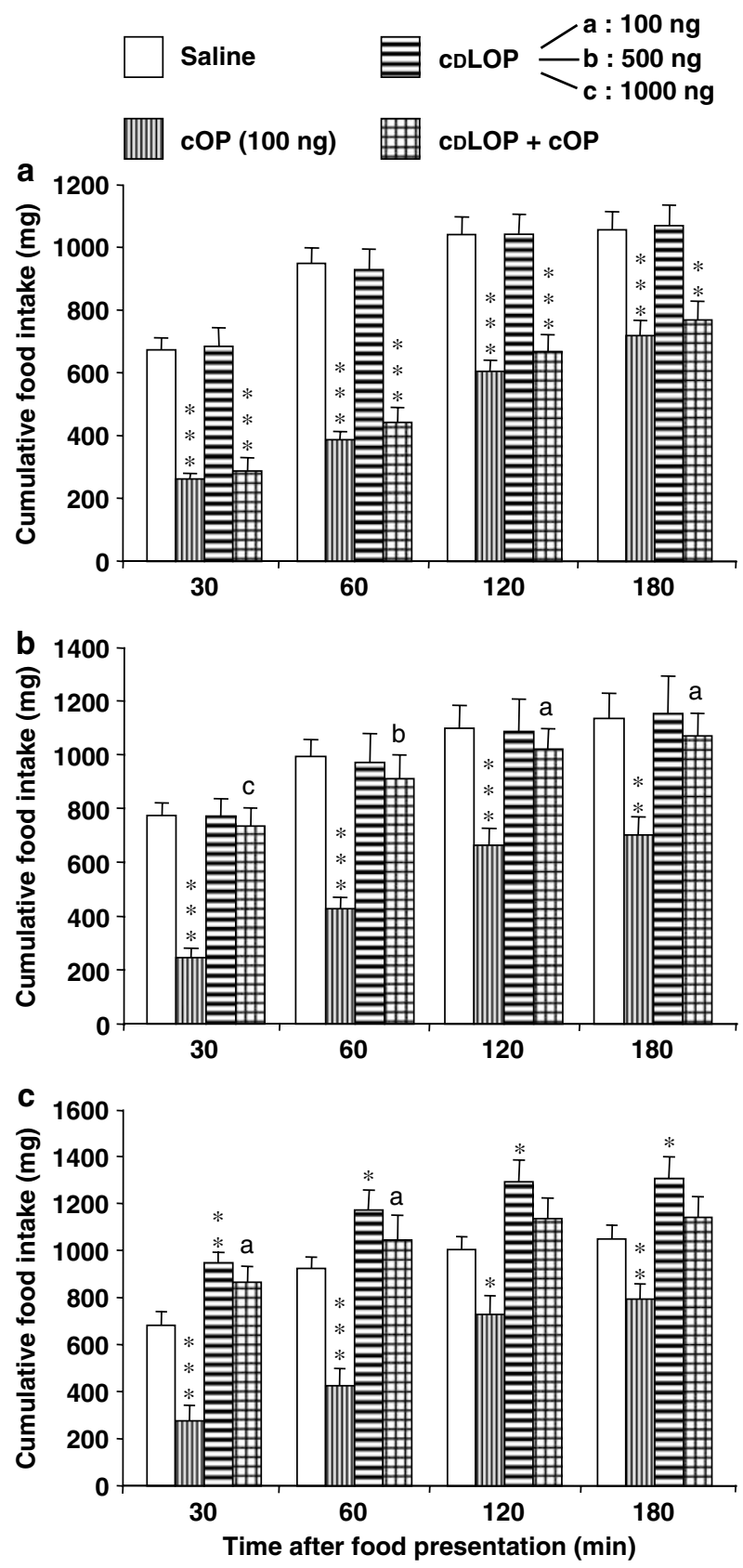

Figure 6 Effect of graded doses of $C D L O P$ on $C O P$-induced inhibition of food intake in food-deprived mice. Mice deprived of food for $18 \mathrm{~h}$, were injected i.c.v. $(|0 \mu|)$ with saline or $\mathrm{COP}(100 \mathrm{ng} /$ mouse) in the absence or presence of increasing doses of cyclo -_ $_{2}\left[\mathrm{DLeu}^{5}\right] \mathrm{OP}$ (CDLOP; a, $100 \mathrm{ng} / \mathrm{mouse}$; b, $500 \mathrm{ng} / \mathrm{mouse}$ c, $1000 \mathrm{ng} / \mathrm{mouse}$ ). Ten min after i.c.v. injection, each animal had access to a weighed food pellet. Cumulative food intake was determined during $3 \mathrm{~h}$ at the time indicated. Mean \pm SEM represents data from 10 to 24 mice per group. Student-Newman-Keuls test ${ }^{*} p<0.05$, ${ }^{*} p<0.0$ I, **** $p<0.001$ vs saline-injected mice. A two-way ANOVA revealed a significant interaction: between CDLOP (500 ng/mouse) and COP at $30 \mathrm{~min}$ $F(I, 44)=19.5,{ }^{c} p<0.001$, at $60 \mathrm{~min} F(I, 44)=10.2,{ }^{b} p<0.01$, at $120 \mathrm{~min}$ $F(I, 44)=4 . I,{ }^{a} p<0.05$, and at $180 \mathrm{~min} F(I, 44)=4 . I,{ }^{a} p<0.05$ after food presentation; and between cDLOP (I000 ng/mouse) and ODN at 30 and 60 min after food presentation $F(I .36)=7.4,{ }^{a} p<0.05$ and $F(I, 36)=5.5$, ${ }^{a} p<0.05$, respectively.

before i.c.v. administration of ODN, had no effect on ODN-induced inhibition of food intake during the 3-h test period (Figure 3a). The inhibitory effect of

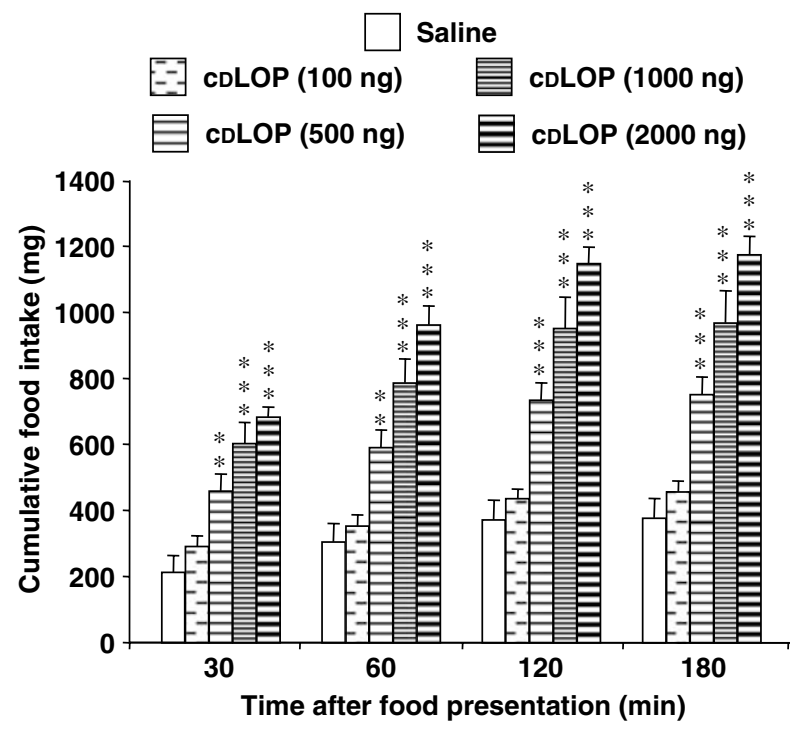

Figure 7 Effect of graded doses of CDLOP on food intake in foodrestricted mice. Mice were food restricted (half of their daily food consumption) for $18 \mathrm{~h}$ and then injected i.c.v. $(|O \mu|)$ with saline or increasing doses of cyclo I-8 $_{2}\left[\mathrm{DLeu}^{5}\right] \mathrm{OP}$ (CDLOP; I00-2000 ng/mouse). Ten min after i.c.v. injection, each animal had access to a weighed food pellet. Cumulative food intake was determined during $3 \mathrm{~h}$ at the time indicated. Mean \pm SEM represents data from 10 mice per group. Student-NewmanKeuls test: $* * * 0.01$, ${ }^{*} * * * 0.00$ I vs saline-injected mice.

ODN was not affected either by i.c.v. co-administration of flumazenil or PK11195 (Figure 3b). At the lowest dose tested ( $100 \mathrm{ng} /$ mouse, i.c.v.), cDLOP did not impair the anorexigenic effect of ODN (Figure 4a), OP (Figure 5a) and cOP (Figure 6a) in food-deprived mice. At higher doses (500 and $1000 \mathrm{ng} / \mathrm{mouse}$, i.c.v.) cDLOP totally suppressed the inhibitory effect of ODN (Figure $4 \mathrm{~b}$ and $\mathrm{c}$ ), OP (Figure $5 \mathrm{~b}$ and $\mathrm{c}$ ) and cOP (Figure $6 \mathrm{~b}$ and $\mathrm{c}$ ) on food intake. At the highest dose tested (1000 ng/mouse, i.c.v.), CDLOP significantly increased food consumption in fooddeprived mice, throughout the 3 -h observation period (Figures $4 c, 5 c$ and $6 c$ ).

\section{Effect of cDLOP on Food Intake in Food-Restricted Mice}

In mice that received approximately half of their daily consumption of food for $18 \mathrm{~h}(1500-0900)$, i.c.v. administration of graded doses of cDLOP (100-2000 ng/ mouse) provoked a dose-related increase of cumulative food intake reaching statistical significance at a dose of $500 \mathrm{ng} /$ mouse (Figure 7). For doses ranging from 500 to $2000 \mathrm{ng} /$ mouse, cDLOP induced a significant orexigenic effect during the whole duration of the test with an increase in cumulative food consumption of $98.1 \pm 13.8 \%$ for the $500 \mathrm{ng}$ dose, $155.1 \pm 25.6 \%$ for the $1000 \mathrm{ng}$, and $209.2 \pm 14.6$ for the $2000 \mathrm{ng}$ dose, at the end of the 3 -h test period (Figure 7).

\section{Effects of Flumazenil, PK11195, and ODN on cDLOP-Induced Orexigenic Effect in Food-Restricted Mice}

I.c.v. administration of flumazenil ( $2 \mu \mathrm{g} /$ mouse $)$ or PK11195 ( $2 \mu \mathrm{g} /$ mouse) in food-restricted mice had no effect on food 


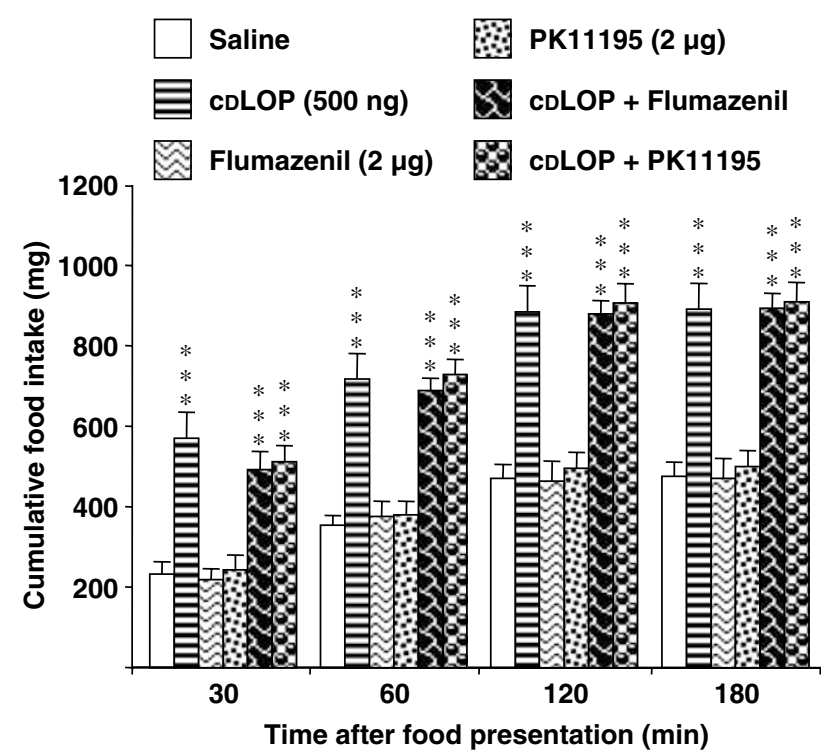

Figure 8 Effect of flumazenil or PK I I 95 on cDLOP-induced increase of food intake in food-restricted mice. Mice were food restricted (half of their daily food consumption) for $18 \mathrm{~h}$ and then injected i.c.v. $(|0 \mu|)$ with saline,

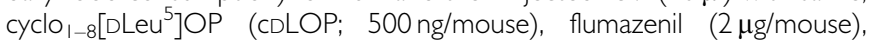
PKI II 95 (2 $\mu \mathrm{g} /$ mouse) or with cDLOP plus flumazenil or PKI I 195. Ten min after i.c.v. injection, each animal had access to a weighed food pellet. Cumulative food intake was measured during $3 \mathrm{~h}$ at the time indicated. Mean \pm SEM represents data from 12 mice per group. Student-NewmanKeuls test: $* * * * 0.00$ I vs saline-injected mice.

consumption and did not significantly alter the orexigenic effect of cDLOP (500 ng/mouse), during the whole 3-h test period (Figure 8). In contrast, i.c.v. co-administration of ODN $(10,100,200$, or $300 \mathrm{ng} /$ mouse) with cDLOP (500 ng/ mouse) reversed the orexigenic effect of $\mathrm{CDLOP}$ and dose dependently restored its own anorexigenic effect (Figure 9). When injected alone, increasing doses of ODN $(100,200$, and $300 \mathrm{ng} / \mathrm{mouse}$ ) dose dependently and significantly decreased $(p<0.05-0.001)$ the cumulative food intake in food-restricted mice (Figure 9).

\section{DISCUSSION}

It has previously been reported that very low doses of ODN inhibit food intake in rat and mice (Garcia de MateosVerchere et al, 2001) but the pharmacological profile of the receptor involved in the effect of ODN had not been characterized. In the present study, we show that the anorexigenic action of ODN is mimicked by the C-terminal fragment of ODN (OP) and its head-to-tail cyclic analog (cOP). Indeed, the C-terminal domain of ODN is capable of inducing several of the effects of ODN such as the anxiogenic activity (Garcia de Mateos-Verchere et al, 1998a), the inhibition of apomorphine-induced yawning (Garcia de Mateos-Verchere et al, 1998b) and the inhibition of pentylenetetrazol-induced convulsions (Garcia de Mateos-Verchere et al, 1999). Interestingly, in the present study, we did not observe any effect of ODN, OP, or cOP on motor activity, indicating that the inhibitory effect of ODN and related peptides on food consumption could not be ascribed to a sedation or psychostimulant activity of these compounds.
It is now clearly established that ODN can interact with CBR associated with the $\mathrm{GABA}_{\mathrm{A}}$ receptor (Ferrero et al, 1986; Tonon et al, 1989; Slobodyansky et al, 1990). In addition, it has been shown that several of the effects induced by ODN are mediated via a G-proteincoupled receptor. In particular, in vitro studies have shown that ODN increases intracellular calcium concentration in cultured rat astrocytes through activation of a metabotropic receptor positively coupled to phospholipase C (Patte et al, 1995; Gandolfo et al, 1997). We have previously observed that the inhibitory effect of ODN on feeding behavior is not affected by diazepam, a mixed CBR and PBR agonist (Garcia de Mateos-Verchere et al, 2001). In order to further characterize the type of receptor mediating the anorexigenic action of ODN and its analogs, in the present study we have investigated the effect of selective endozepine receptor antagonists on $\mathrm{ODN}, \mathrm{OP}$, and cOP-induced food consumption. The specific CBR antagonist flumazenil (Bonetti et al, 1982) and the specific PBR antagonist PK11195 (Le Fur et al, 1983) did not prevent the inhibitory effect of ODN, OP, and $\mathrm{COP}$ on food intake. Conversely, cDLOP, which acts as a metabotropic endozepine receptor antagonist (Leprince et al, 2001), suppressed the anorexigenic effect of ODN, OP, and cOP. These data indicate that the effects of ODN and its analogs on feeding behavior are mediated through activation of the recently characterized metabotropic receptor. Moreover, at the highest dose tested ( $1000 \mathrm{ng} / \mathrm{mouse})$, CDLOP not only suppressed the inhibitory effect of ODN on food intake, but significantly increased by its own food consumption, indicating that endogenous ligands of the metabotropic endozepine receptor, including ODN, exert a tonic inhibitory effect on feeding behavior. Of note, $\mathrm{CDLOP}$ has already been used successfully to decipher physiological actions of endozepines in the brain. Thus, it has been recently shown that CDLOP not only prevented the inhibitory effects of ODN on gonadotropin-releasing hormone $(\mathrm{GnRH})$ and NPY gene expression but also increased by itself GnRH and NPY mRNA levels (Compère et al, 2004, 2005). Consistent with an endozepinergic tonus controlling feeding, in the present study, we found that the stimulatory action of cDLOP on food consumption was completely abolished by ODN. These data indicate that the orexigenic effect of cDLOP and the anorexigenic effect of ODN are mediated through activation of the same receptor. This latter observation provides strong evidence for the involvement of endozepine metabotropic receptors in the control of feeding.

In conclusion, the present study provides direct evidence that, in mice, the anorexigenic effect of ODN involves receptors that are distinct from the classical CBR and PBR. The pharmacological profile of these receptors corresponds to that of the metabotropic endozepine receptor positively coupled to phospholipase C. Our results also suggest the existence of an endozepinergic tonus that appears to play an important role in the regulation of feeding behavior.

\section{ACKNOWLEDGEMENTS}

This work was supported by grants from CNRS (FRE 2735), Inserm (U413), the Regional Platform for Cell Imaging, the 


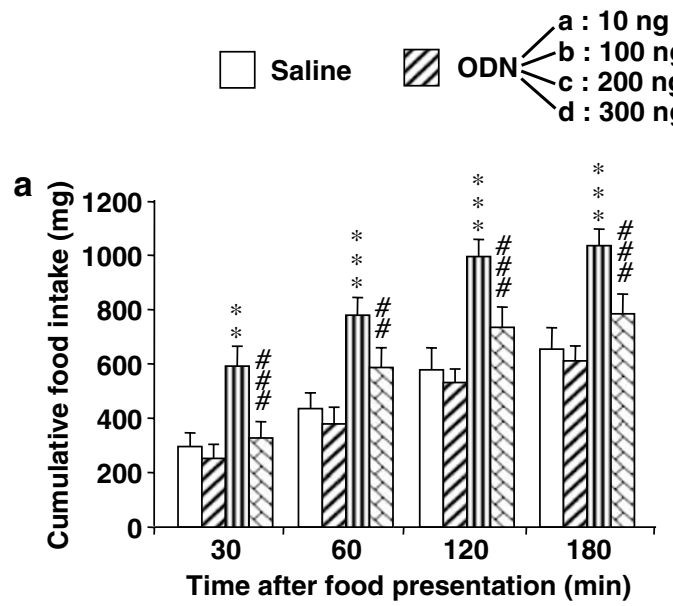

\section{CDLOP + ODN III CDLOP (500 ng)}
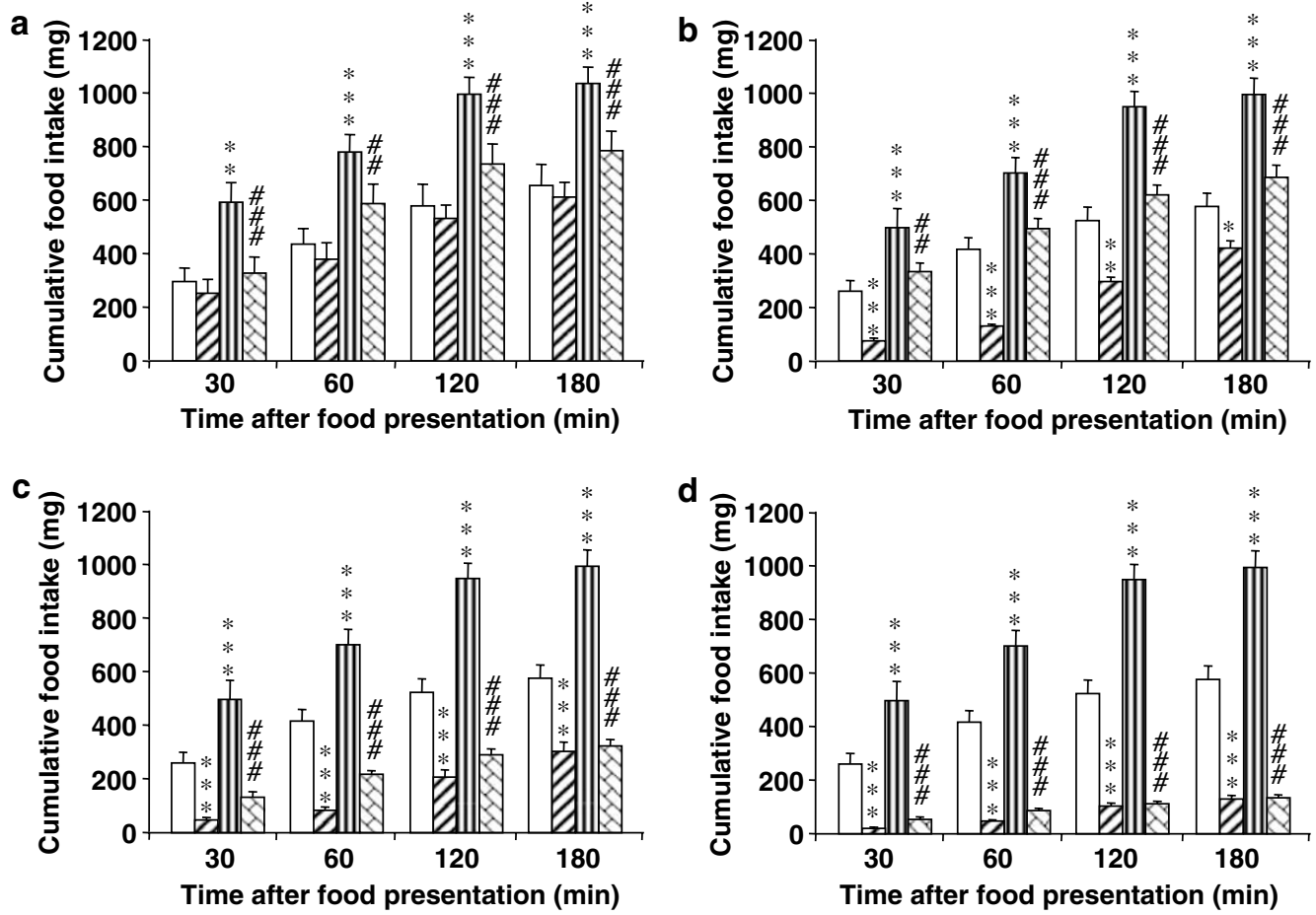

Figure 9 Effect of graded doses of ODN on CDLOP-induced increase of food intake in food-restricted mice. Mice were food restricted (half of their daily food consumption) for $18 \mathrm{~h}$ and then injected i.c.v. $(10 \mu \mathrm{l})$ with saline or cyclo $-8\left[\mathrm{DLeu}{ }^{5}\right] \mathrm{OP}(\mathrm{CDLOP} ; 500 \mathrm{ng} / \mathrm{mouse})$ in the absence or presence of increasing doses of ODN (a, 10 ng/mouse; b, 100 ng/mouse; c, 200 ng/mouse; d, 300 ng/mouse). Ten min after i.c.v. injection, each animal had access to a weighed food pellet. Cumulative food intake was measured during $3 \mathrm{~h}$ at the time indicated. Mean \pm SEM represents data from $10-20$ mice per group. Student-NewmanKeuls test post hoc: ${ }^{*} p<0.05$, *** $p<0.01$, *** $p<0.001$ vs saline-injected mice; ${ }^{\# \#} p<0.01$, \#\#\# $p<0.001$ vs cDLOP-injected mice. A two-way ANOVA revealed a significant interaction between $O D N$ and $c D L O P$ : at $30 \mathrm{~min} F(4, I 10)=4.01, p<0.01$, at $60 \mathrm{~min} F(4, I I 0)=5.2$, $p<0.001$, at I20 min $F(4,|| 0)=8.75, p<0.00 \mid$, and at I $80 \min F(4,|| 0)=8 .|3, p<0.00|$.

European Institute for Peptide Research (IFRMP 23), and the Conseil Régional de Haute-Normandie.

\section{REFERENCES}

Alho H, Costa E, Ferrero P, Fujimoto M, Cosenza-Murphy D, Guidotti A (1985). Diazepam-binding inhibitor: a neuropeptide located in selected neuronal populations of rat brain. Science 229: 179-182.

Alho H, Fremeau Jr RT, Tiedge H, Wilcox J, Bovolin P, Roberts JL et al (1988). Diazepam binding inhibitor gene expression: location in brain and peripheral tissues of rat. Proc Natl Acad Sci USA 85: 7018-7022.

Berkovich A, McPhie P, Campagnone M, Guidotti A, Hensley P (1990). A natural processing product of rat diazepam binding inhibitor, triakontatetraneuropeptide (diazepam binding inhibitor 17-50) contains an alpha-helix, which allows discrimination between benzodiazepine binding site subtypes. Mol Pharmacol 37: 164-172.

Bonetti EP, Pieri L, Cumin R, Schaffner R, Pieri M, Gamzu ER et al (1982). Benzodiazepine antagonist RO 15-1788: neurological and behavioral effects. Psychopharmacology 78: 8-18.

Bormann J (1991). Electrophysiological characterization of diazepam binding inhibitor (DBI) on $\mathrm{GABA}_{\mathrm{A}}$ receptors. Neuropharmacology 30: 1387-1389.

Compère V, Li S, Leprince J, Tonon MC, Vaudry H, Pelletier G (2003). Effect of intracerebroventricular administration of the octadecaneuropeptide on the expression of pro-opiomelanocortin, neuropeptide $\mathrm{Y}$ and corticotropin-releasing hormone mRNAs in rat hypothalamus. J Neuroendocrinol 15: 197-203.

Compère V, Li S, Leprince J, Tonon MC, Vaudry H, Pelletier G (2004). In vivo action of a new octadecaneuropeptide (ODN) antagonist on gonadotropin-releasing hormone gene expression in the male rat brain. Neuroscience 125: 411-415.

Compère V, Li S, Leprince J, Tonon MC, Vaudry H, Pelletier G (2005). In vivo action of a new octadecaneuropeptide antagonist on neuropeptide $\mathrm{Y}$ and corticotropin-releasing hormone mRNA levels in rat. Mol Brain Res 141: 156-160.

Ferrero P, Santi MR, Conti-Tronconi B, Costa E, Guidotti A (1986). Study of an octadecaneuropeptide derived from diazepam binding inhibitor (DBI): biological activity and presence in rat brain. Proc Natl Acad Sci USA 83: 827-831.

Gandolfo P, Louiset E, Patte C, Leprince J, Masmoudi O, Malagon $M$ et al (2001). The triakontatetraneuropeptide TTN increases $\left[\mathrm{Ca}^{2+}\right]_{\mathrm{i}}$ in rat astrocytes through activation of peripheral-type benzodiazepine receptors. Glia 35: 90-100.

Gandolfo P, Patte C, Leprince J, Thoumas JL, Vaudry H, Tonon MC (1997). The stimulatory effect of the octadecaneuropeptide (ODN) on cytosolic $\mathrm{Ca}^{2+}$ in rat astrocytes is not mediated through classical benzodiazepine receptors. Eur J Pharmacol 322: 275-281.

Garcia de Mateos-Verchere J, Leprince J, Tonon MC, Vaudry H, Costentin J (1998a). The octadecaneuropeptide ODN induces anxiety in rodents: possible involvement of a shorter biologically active fragment. Peptides 19: 841-848. 
Garcia de Mateos-Verchere J, Leprince J, Tonon MC, Vaudry H, Costentin J (1998b). The octadecaneuropeptide ODN inhibits apomorphine-induced yawning in rats. Eur J Pharmacol 357: 121-126.

Garcia de Mateos-Verchere J, Leprince J, Tonon MC, Vaudry H, Costentin J (1999). Reduction of pentylenetetrazol-induced convulsions by the octadecaneuropeptide ODN. Peptides 20: 1431-1436.

Garcia de Mateos-Verchere J, Leprince J, Tonon MC, Vaudry H, Costentin J (2001). The octadecaneuropeptide (diazepam-binding inhibitor (33-50)) exerts potent anorexigenic effects in rodents. Eur J Pharmacol 414: 225-231.

Guidotti A, Alho H, Berkovich A, Cox DH, Ferrarese C, Slobodyansky E et al (1989). DBI processing: allosteric modulation at different GABA/benzodiazepine receptor subtypes. In: Barnard EA, Costa E (eds). Allosteric Modulation of Amino Acid Receptors: Therapeutic Implications. Raven Press, Ltd: New York. pp 109-123.

Guidotti A, Forchetti CM, Corda MG, Konkel D, Bennett CD, Costa E (1983). Isolation, characterization and purification to homogeneity of an endogenous polypeptide with agonistic action on benzodiazepine receptors. Proc Natl Acad Sci USA 80: 35313535.

Haley TJ, McCormick WG (1957). Pharmacological effects produced by intracerebral injection of drugs in the conscious mouse. Br J Pharmacol 12: 12-15.

Le Fur G, Guilloux F, Rufat P, Uzan A, Renault C, Dubroeucq MC et al (1983). Peripheral benzodiazepine binding sites: effects of PK11195, 1-(2-chloro-phenyl)-N-(1-methylpropyl)-3isoquinolinecarboxamide. II. In vivo studies. Life Sci 32: 1849-1856.

Leprince J, Gandolfo P, Thoumas JL, Patte C, Fauchère JL, Vaudry $\mathrm{H}$ et al (1998). Structure-activity relationships of a series of analogues of the octadecaneuropeptide ODN on calcium mobilization in rat astrocytes. J Med Chem 41: 44334438.

Leprince J, Oulyadi H, Vaudry D, Masmoudi O, Gandolfo P, Patte C et al (2001). Synthesis, conformational analysis and biological activity of cyclic analogs of the octadecaneuropeptide ODN. Eur J Biochem 268: 6045-6057.
Louiset E, Vaudry H, Cazin L (1993). Allosteric modulation of the GABA-induced chloride current in frog melanotrophs. Ann NY Acad Sci 680: 564-566.

Malagon M, Vaudry H, Van Strien F, Pelletier G, Gracia-Navarro F, Tonon MC (1993). Ontogeny of diazepam-binding inhibitorrelated peptides (endozepines) in the rat brain. Neuroscience 57: 777-786.

Patte C, Vaudry H, Desrues L, Gandolfo P, Strijdveen I, Lamacz M et al (1995). The endozepine ODN stimulates polyphosphoinositide metabolism in rat astrocytes. FEBS Lett 362: 106-110.

Slobodyansky E, Berkovich A, Bovolin P, Wambebe C (1990). The endogenous allosteric modulation of $\mathrm{GABA}_{\mathrm{A}}$ receptor subtypes: a role for the neuronal posttranslational processing products of rat brain DBI. In: Biggio G, Costa E (eds). GABA and Benzodiazepine Receptor Subtypes. Raven Press: New York. pp 51-61.

Slobodyansky E, Guidotti A, Wambebe C, Berkovich A, Costa E (1989). Isolation and characterization of a rat brain triakontatetraneuropeptide, a posttranslational product of diazepam binding inhibitor: specific action at the RO 5-4864 recognition site. J Neurochem 53: 1276-1284.

Tong Y, Toranzo D, Pelletier G (1991). Localization of diazepambinding inhibitor (DBI) mRNA in the rat brain by high resolution in situ hybridisation. Neuropeptides 20: 33-40.

Tonon MC, Adjeroud S, Lamacz M, Louiset E, Danger JM, Desrues $\mathrm{L}$ et al (1989). Central-type benzodiazepines and the octadecaneuropeptide modulate the effects of GABA on the release of alpha-melanocyte-stimulating hormone from frog neurointermediate lobe in vitro. Neuroscience 31: 485-493.

Tonon MC, Désy L, Nicolas P, Vaudry H, Pelletier G (1990). Immunocytochemical localization of the endogenous benzodiazepine ligand octadecaneuropeptide (ODN) in the rat brain. Neuropeptides 15: 17-24.

Tonon MC, Leprince J, Gandolfo P, Compère V, Pelletier G, Malagon $\mathrm{M}$ et al (2006). Endozepines. In: Kastin AJ (ed). Handbook of Biologically Active Peptides. Elsevier, Chapter 10, pp 813-819.

Yanase H, Shimizu H, Yamada K, Iwanaga T (2002). Cellular localization of the diazepam binding inhibitor in glia cells with special reference to its coexistence with brain-type fatty acid binding protein. Arch Histol Cytol 65: 27-36. 